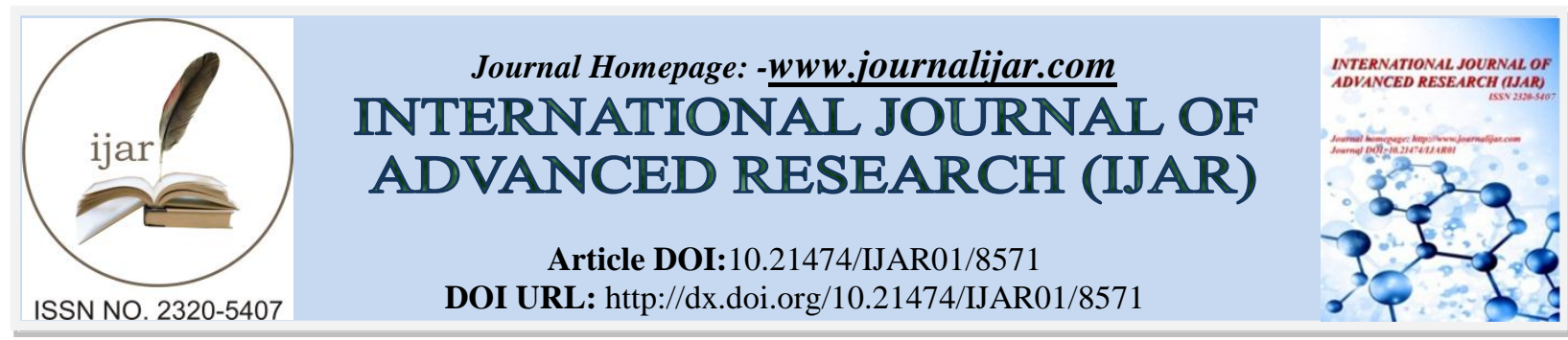

RESEARCH ARTICLE

\title{
TREATMENT OF IDIOPATHIC CARPAL TUNNEL SYNDROME: THE EFFICACY OF LOCAL STEROID INJ. VS. LOCALXYLOCAIN INJ. IN TREATMENT OF IDIOPATHIC CARPAL TUNNEL SYNDROME (I. C.T.S.) (A DOUBLE BLINDED STUDY).
}

Wijdan H.AL-Shami ${ }^{1}$ and Sami Salman ${ }^{2}$.

1. MB.ch.B.,DR- DMR, Specialist Doctor in Rheumatology and Rehabilitation AL-Yarmouk Teaching Hosp.Baghdad/Iraq.

2. Prof. MRCP(UK) Medicine Prof./College Of Medicine, Univ. Of Baghdad/Iraq.

\section{Manuscript Info}

.........................

Manuscript History

Received: 14 December 2018

Final Accepted: 16 January 2019

Published: February 2019

Key words:-

Behaviour, determinant, factor, health, seeking.

\section{Abstract}

Background:Locale injections (using steroid \pm a local anesthetic) for treatment of carpal tunnel syndrome (C.T.S) is widely known \& studied as asafe \&effective conservative way of treatment. ${ }^{(1,2,3,4,5,6,7,7)}$ Aim of this study is to compare the efficacy of using each alone on treatment results

Pts.\&methods:77pts with (I.C.T.S) were subjected to a double blind study putting them into two comparable groups \& subjecting them to local e inj.into the carpal tunnel by either steroid or local anesthetic .pts were evaluated subjectively ,

Objectively and electrophysiologicaly pre and one moths post injection .

Results : were in favour of steroid group with significant improvement of most symptoms and signs $(\mathrm{p}<0.01)$

All electrophysiological abnormalities improved significantly $(\mathrm{p}<0.001)$ in steroid group while not in xylocain group (a part from SAP-amp.)

Conclusion :It looks that steroid alone has a superior effect over xylocain alone in treating I.C.T.S by local inj.

Copy Right, IJAR, 2019,. All rights reserved.

\section{Introduction:-}

Carpal tunnel syndrome (CTS) ( The compression of median nerve in the carpal tunnel, McArdle 1951) can be idiopathic ( I.C.T.S)or secondary to many causes ${ }^{(9)}$.

Local steroid inj. was mentioned for first time as a type of conservative treatment by (Phalen and Kindrick 1957 )$^{(10)}$, since then different studies were done to compare conservative vs .surgical decompression of the median nerve $(11,12,13)$, and to compare local steroid effect vs systemic steroid ${ }^{(14)}$ and vs .other different conservative ways of treatment ${ }^{(10)}$ (splinting ${ }^{(15)}$,lontophoresis $\left.{ }^{(16)}\right)$.

For local injections steroid \pm a local anesthetic is used usually and successfully ${ }^{(1-8)}$.

Corresponding Author:-Wijdan H.AL-Shami.

Address:-MB.ch.B.,DR- DMR, Specialist Doctor in Rheumatology and Rehabilitation AL-

Yarmouk Teaching Hosp.Baghdad/Iraq. 
Mechanism of action was attribted to anti-inflammatory effect or a mechanical effect (displacing some thing which was compressing the nerve $)^{(1,10)}$

This is a double blind study to compare the efficacy of using steroid alone vs anesthetic alone in treating pts . which I.C.T.S. by local inj.

\section{Patients and Methods:-}

77 patients with I.C.T.S .(presented to rheunatol. consult .clinic / medical city, Baghdad ) 64 females and 30 males their mean age was $38 \pm 11.5$ years, duration of sympts. $\geq 3$ moths occupation: house wife $76 \%$ teacher $9.2 \%$ clerk $5.5 \%$ labourir $5.5 \%$ and farmer $1.9 \%$. All were evaluated:

1. Clinically by (phalentest, Tinel's test, Pin Prick sens ., power of A.P.B and OP.bsides horizontal V.A.S. for severity of symptoms.)

2. Subjected to electrophysiological study (EMG/NCS) of both Ulnar and Median nerves of affected hands .

3. ( Note : C.T.S was diagnosed if : median $\mathrm{n}$. showed $\mathrm{DML}>4.1 \mathrm{~m} \mathrm{sec}, \mathrm{SAP}-\mathrm{L}>3.7 \mathrm{msec}$, median $\mathrm{SAP}-\mathrm{amp}$ : Ulnar SAP - amp $=<1$ )

4. All secondary C .T.S cases (due to inflammatory arthritis, degenerative, traumatic, endocrine causes beside pregnancy and lactation )

1. Were excluded by history, laboratory tests, $x$ - rays of affected hands.

2. Patients were randomly allocated, into two comparable groups ( regarding sex ,age, occupation duration and severity of symptoms .

3. Treatment was given in a double blind way as follows :

4. Group A : $0.5 \mathrm{ml}(20 \mathrm{mg})$ of triamcinolone Acetonide.

5. Group B : $0.5 \mathrm{ml}$ of $2 \%$ Xylocain .

6. Patients were asked to continue their normal daiely activities and occupations and to avoid other treatments especially NSAIDs .

7. Re - evaluation was done one month later by the same way .

8. At the end: comprison between the two groups was done by using Chi Square test for sympts and signs Paired $t$ tests for V.A.S and electro physiological studies .

\section{Results:-}

Subjective evaluations

symptomatic

\begin{tabular}{|c|c|c|}
\hline Over all symptomatic improvement & Group A (steroid ) & Group B( $2 \%$ xylocain $)$ \\
\hline 1- Mean $\%$ of improvement $/ \mathrm{PtFeeling}$. & $69 \%$ & $46.8 \%$ \\
\hline \multirow{4}{*}{$\begin{array}{l}\text { 2- Final results of treatment } \\
100 \% \text { improve .(symptomfree ) } \\
\text { Mild moderate improve. } \\
\text { No improve }\end{array}$} & & \\
\hline & $18.8 \%$ & $26.5 \%$ \\
\hline & $76.7 \%$ & $50 \%$ \\
\hline & $4.7 \%$ & $23.5 \%$ \\
\hline $\begin{array}{l}\text { 3- Mean number of paracetmol tabs needed / } \\
\text { 30 days }\end{array}$ & 11 & 16 \\
\hline
\end{tabular}

Severity of symptoms

Horizontal V.AS .

\begin{tabular}{|c|c|c|c|c|}
\hline & Before R & \multicolumn{2}{|c|}{ After R } & \multicolumn{2}{|c|}{ Significance } \\
\cline { 3 - 5 } & & & T value & P value \\
\hline Group A( steroid ) & 6.6 & 2.1 & 11.78 & P $>0.001$ \\
\hline Group B (2\% xylocain ) & 7 & 3.9 & 5.9 & P $>0.001$ \\
\hline
\end{tabular}


Objective ( clinicalassements )

\begin{tabular}{|c|c|c|c|c|c|c|}
\hline \multirow[t]{2}{*}{ Signs } & \multicolumn{2}{|c|}{ Group A ( steroid ) } & \multicolumn{2}{|c|}{ Group B ( 2\%xylocain ) } & \multicolumn{2}{|c|}{ Significance } \\
\hline & Turn - -- ve & $\begin{array}{c}\text { Not } \\
\text { changed }\end{array}$ & Turn - ve & Not changed & $\mathrm{X}_{2}$ & $\mathrm{P}$ \\
\hline +vePhalen test & $48 \%$ & $52 \%$ & $43 \%$ & $57 \%$ & 0.17 & N.S \\
\hline +veTinel's test & $30.5 \%$ & $69.5 \%$ & $30.5 \%$ & $62.5 \%$ & 0.003 & N.S \\
\hline Hypo-algesia & $38 \%$ & $62 \%$ & $6.5 \%$ & $94 \%$ & 0.002 & N.S \\
\hline Hyper- algesia & $28.5 \%$ & $71.5 \%$ & $25 \%$ & $75 \%$ & 0.12 & N.S \\
\hline (weakness) & $34.5 \%$ & $65.5 \%$ & $32 \%$ & $68 \%$ & 0.033 & N.S \\
\hline
\end{tabular}

\section{Objective : ( electrophysiological assements)}

\begin{tabular}{|c|c|c|c|c|c|c|c|c|}
\hline EMG / NCV indices & \multicolumn{4}{|c|}{ Group A( steroid ) } & \multicolumn{4}{|c|}{ Group $\mathrm{B}(2 \%$ xylocain $)$} \\
\hline DML (msec) & $\begin{array}{c}\text { Before } \\
\text { Rx }\end{array}$ & $\begin{array}{l}\text { After } \\
\text { Rx }\end{array}$ & $\begin{array}{c}\mathrm{T} \\
\text { value }\end{array}$ & $\begin{array}{c}\mathrm{P} \\
\text { value }\end{array}$ & $\begin{array}{c}\text { Before } \\
\text { Rx }\end{array}$ & $\begin{array}{c}\text { After } \\
\text { Rx }\end{array}$ & $\begin{array}{c}\mathrm{T} \\
\text { value }\end{array}$ & $\begin{array}{c}\mathrm{P} \\
\text { value }\end{array}$ \\
\hline DML $(\mathrm{m} \mathrm{sec})$ & 5.3 & 4.7 & 5 & $\mathrm{p}<0.001$ & 4.5 & 4.4 & 0.9 & N.s \\
\hline SAPL ( m sec ) & 4.7 & 3.9 & 6.2 & $\mathrm{p}<0.001$ & 4.6 & 4.3 & 1.8 & N.s \\
\hline $\mathrm{SAP}-\operatorname{amp}(\mathrm{m} \cdot \mathrm{v})$ & 6.2 & 8.4 & 4.3 & $\mathrm{p}<0.001$ & 4.7 & 3.4 & 4.1 & $\begin{array}{c}\mathrm{p}< \\
0.001\end{array}$ \\
\hline $\operatorname{NCV}(\mathrm{m} / \mathrm{sec})$ & 61.9 & 65.8 & 4.2 & $\mathrm{p}<0.001$ & 60.1 & 61.5 & 0.9 & N.S \\
\hline
\end{tabular}

\section{Discussion:-}

1. Electrophysiological study is the most accurate diagnostic measure ,the best way ofassenment of severity of nerve compassion and of results of treatment (Deckers $)^{(17,18)}$.

2. We re-valuated our patients one month post treatments because this is the minimal period needed for expecting changes in electrophysiological indicines ${ }^{(2,19,20,21)}$.

3. A Certain $\%$ of C. T.S cases are self -limitting( complete remission )due to resting of affected hand or changing accupation $(10,23)$ 'therefore we instructed our patients to continue their usual jobs and A.D.L .Assessments of our results showed :

4. In the subjective feelings of pts :

5. Steroid group did slightly better thanxylocain group (with a significant difference in both groups ) in most of the presenting symptoms .

6. Electrophysiologicaly : steroid was more effective in improving all parameter (but no . pt returned to normal in all parameters simultaneously) .

7. DML and SPA - L returned to normal in only some patients ( more in steroid group )

8. Spontaneous activity/ thenarms. - disappeared in the both groups ( cured )

\section{Conclusion:-}

Its looks that steroid alone has a superior effect overxylocain alone and this may be due to both anti inflammatory and mechanical effect of steroid vs only mechanical

( volume ) effect of xylocain

\section{References:-}

1. V. Agarwal, R.Smgh, A.Sachderet a(2005)l.A prospective study of the long term efficacy of local methylprednisolone acetate inj. In the management of mild C.T.S.Rheumatology (oxford) 44: 647-650

2. F.F Ayhan ,Ardic\& H.R. Erdem (2000 ): Long term clinical \&electrophysiological results of local steroid inj.In patients wich C.T.SFunct. Neuro1 15: 157-165 
3. P.Girlanda, R.D. attole, C. Venutoetal(1993 )Local steroid treatment in I.C.T.S. a shirt \&long term efficacy (Randomized control trial)J. Neuroal $240:(187-190)$

4. H.Ozdogan , H. Yazici(1984)The efficacy of local steroid inj. In I.C.T.S. (a clonally blind study)Br.J. Rheumatol $23:(272-257)$

5. S. Marshall, G. Tardif \& N. Ashworth (2007)Local corticosteroid inj. For C.T.S. (Review article)Cochrane data base syst. Rev. 2.

6. D.O Gradaigh\&P. Merry(2000)Corticosteroid inj. For treatment C.T.S.Ann Rheum Dis.59:(918-919)

7. J.A. Schuchman ,Meluin ,R.J. Duran etal(1971)Evaluation of local steroid inj. For C.T.S.Arch phys. Med. Rehabil $52:(253-255)$

8. Timothy Armstrong M.D,William, Devor MD Laura Borsched M.P.H. etal(2003)Intra carpal steroid inj. Is safe $\&$ effective for short term managementof C.T.S. Muscle \&Nerve vol 29 issue 1 Nov.

9. Frazblan and R.A. wener(1999) What is C.T.S. ?JAMA 282: (186-187)

10. PhalenG.S(1966)The C.T.S. : 17 year experience in diagnosis \& treatmentof645 HandJournal. Bone \& Joint surg. 48 A (211-223).

11. Demirci, S. Kutluhan, H.R. Koyunogluetal(2002 )Comparison of open C.T. release \& local stroid treatment outcomeIn I.C.T.S. Rheumatol. Int. 22 (33-37)

12. DavoodJafari ,Hoomanshariatzadeh, Farid NajdMazharetal(2018)Comparison of the efficacy of carpal tunnel release VS. local steroid inj. In the management of mild to moderate C.T.S. (a clinical trial)Shafa Orthopedic Journal 5(1) e 58159

13. Hui.AC.,WongSM.Leung CH. etal(2005 ) Arandomized controlled trial of surgery VS. Steroid inj . Neurology , 64(12 ) 2074-8 doi.

14. Wong SM etal (2001)Local VS. systemic corticosteroid in the treatment of C.T.S.Neurology 12 , 56(11) 1431-2

15. R.H Gelberman ,D.Aronson\& M.H Weisman (1980 ) C.T.S : results of a prospective trial of steroid inj.\& splintingJournal .Bone \&Joint Surg. 62-A no.7. 1181-1184 .

16. Campittili P. \& pace P. (ospedale di Jesi/ (ltal)C.T.S. infiltration or iontophoresis pRiabilitizione 22/1: (57-62).

17. Deckers H., Vansteen land H\&RosselleN(1968 ).EMG Findings in C.T.S.Rheumatolatal .Med. Phys. $23 / 6$ (269-280)196 .

18. M.W Keith, V. Master etal(2009)Diagnosis of C.T.S.J. Am Acadorthosurg. 17 (6): 389-391

19. Goodman H.V.\&Foster J.B( 1962) .Effect of local steroid inj. On median n.conduction in patients with C.T.S. Ann.phys.med.6 (287-294) .

20. Ghantraine A, ALbassir Gerard R. Balthazar Letaws R.(Hop univ. de-baviere Liege) (1969)Electrical findings during the Course of C.T.S.Ann. Med. Phys. 12/2 (162-170)

21. Exp. Med. sec. 19 vol 131970

22. Fiesser U , Holdorff B. (NeuroklinklinStiglitzFreieuni v . Berlin GFR)(1981)

23. Clinical \&EMG follow up in conservatively treated C.T.S.Actual neural 8/2 (93-96)

24. E.E Hagebeuk\& A.W. Edeweerd(2004) Clinical \&electrophysiological follow up after local steroid inj. in C.T.S.Clin .Neurophysiol115 1464-1468.

25. R.S Crow M.D .MRCP senior Medical Registrar ( Bristol Royal Infermery )(1960)Treatment of C.T.SB.M.J .May $28(1611-1615)$. 